\title{
Variable Husbandry and Changing Climate
}

\section{Cattle Breeding and Permafrost Soil in Yakutia}

\author{
Csaba Mészáros \\ Institute of Ethnology, RCH, Hungarian Academy of Sciences, Budapest
}

\begin{abstract}
The author focuses on the changing perception and use of alaases (round shaped meadows in thermocarst depressions) in a Central-Yakutian village community under the effect of global climate change. Households of the local cattle-economy before the collectivisation used to be located at alaases and had used small and disperse hayfields. Subsequent economic reforms in the Soviet era, and the process of decollectivisation (in the 1990s) distanced villagers from alaases. Therefore knowledge on alaas ecotope in the village has radically diminished.

In the $21^{\text {st }}$ century environmental changes have had negative effect on the local agriculture and economy. Increase in annual precipitation, and in mean annual temperature resulted in the rapid humidification of permafrost soil, and the degradation of hayfields. Three factors expose today agricultural production in the village to ongoing climatic changes: low level of selfdependency in agricultural production, undiversified production of unprocessed raw material, and the vanishing concepts of local spiritual ecology. The author argues that anthropological research can effectively contribute to the mitigation of losses in Sakha cattle economy by studying traditional methods of land use and the perception of environment.
\end{abstract}

Keywords: environmental anthropology, climate change, arctic region, sustainability

\section{CULTURE AND NATURE}

In the social sciences, the opposition of nature (the physical space and environment not created by man) and culture has been an essential element of the modernist episteme (DesCOLA 2013:78 -83). The ethnographic and anthropological works influenced by this approach presumed that social and cultural processes that occur against the backdrop of the natural environment - which is static or changing imperceptibly - obey completely different rules (DeGler 1989). Although the two spheres may come into contact with each other, they are essentially disparate and dissociable.

This approach has been widely criticized since the 1950s. The first approach to be distinctly formulated was the one representing the ecological determination of human cultures. The school of cultural ecology, hallmarked by Julian Steward, primarily 
debated the validity of studies fostered by the legacy of Franz Boas and Alfred Kroeber, arguing for the ecological determination of cultures instead of the notion of nature being in contrast and subordinated to human culture (STEWARD 1955). Culture and nature created two disparate spheres within this conceptual framework; the contact between them, their interface, is created by the totality of knowledge and practices, called the "cultural core" by Steward, and which in this model can be considered a set of techniques of adapting (primarily economically) to the natural environment (STEWARD 1955:37). The epistemological horizon of cultural ecology, as well as of ecological anthropology, which it inspired, is still determined by this approach: the separate spheres of natural environment and human culture are formed by acting upon each other and in conjunction with each other. It also follows that some areas of a community's culture will be more subject to the determination of environmental impact, while others less so. In the interaction between nature and culture, either one or the other sphere will get a more decisive role.

Providing a more radical critique is the approach which calls into question the separability of the natural world and the human culture that "emerges" from it. In anthropology, the foundations of this paradigm were set by Gregory Bateson (BATESON 2000:456-458), then developed by Tim Ingold. According to Ingold, who studied environmental awareness and human behavior within an environment, it cannot be determined where the human world ends and where nature, the physical space - which exists independently - begins, and therefore it is not appropriate to contrast natural and cultural spheres (INGOLD 2000:16-19). Human communities perceive themselves as an integral (an inseparable) part of their environment; they do not accumulate scientific knowledge of plants and animals but rather practical knowledge and skills derived from repetition and experience.

Proponents of the method of perspectivism, based on the study of South American Indian animism, employ a similarly radical commentary in their interpretation of nature and society as separate spheres. Perspectivism questions who (what kind of entities) make up the whole of society (Viveiros de Castro 1998; Descola 2013). A multitude of examples demonstrates that not every community shares the idea that only people may be part of the society. In the Arawate Indians' view, for example, predatory animals see humans as prey, while game animals see them as spirits. Spirits and animals consider themselves human, their abode, meals and appearance as human (jaguars, for example, as they lap blood, drink cassava beer, wear their pelt as a decorative fur). In the diversity of spirit, animal and human points of view, there is no single privileged perspective, since it is possible to move from one role (social situation) to another (for example, through death, birth, or becoming prey).

In this system, it was not the people that emerged from the animal kingdom at one point (see Darwinism), but rather animals and spirits became peculiar parts of a single broad society in which people and animals are distinguished from each other by social rules. On the other hand, according to European modernist ontology, which represents the separation of nature and culture, it is only natural laws that distinguish people (and therefore society as well) from other living beings and from the spirit world. My study, ignoring the conceptual opposition of nature and culture, presents a Siberian community embedded in its environment that continues its cattle husbandry in the $21^{\text {st }}$ century while adapting to the challenges of global climate change and Soviet-era state modernization 
efforts. ${ }^{1}$ In this community, the boundary between the human and non-human spheres is far from clear, which also significantly influences how the locals perceive their environment. I demonstrate the changes caused by climate change in the husbandry system, while also addressing the general processes characteristic of Yakutia, primarily with the example of one village, Tobuluk, with a population of nearly 650, situated in Central Yakutia. ${ }^{2}$

In my paper, I argue that the environment is not just a passive sufferer of human intervention, but an active participant in the ecological processes that determine the long-term viability of human communities in certain regions.

In the subarctic and arctic regions of Yakutia, the speed and scale of climate change affecting the local economy and lifestyle forces the inhabitants of the region into a passive, adaptive position. In this situation, it makes a significant difference in the course of adaptation how a community views the animate environment. Is it the material reality and the ensuing biophysical laws that create the rules and inevitability of co-existence between man and his environment, or is it the spiritual community that unites all living things (people, animals, plants, mountains, fields, living waters) into one broad society and assigns obligations to all parties on ethical grounds?

\section{A DIACHRONIC APPROACH TO ECOLOGICAL AND HUSBANDRY SYSTEMS}

Treating nature and culture as different entities often resulted in researchers applying an anachronistic approach to these spheres, viewing the natural environment as constant, stable (and therefore negligible) when considering it within the study of a culture. One of the best examples of this is the Jesup Expedition, which covers a huge area (the entire northern edge of the Pacific Ocean) (VAKHTIN 2001). Franz Boas, the main organizer and leader of the 1897-1902 expedition, considered a diachronic study important primarily if it examined cultural symbols that developed without regard to the geographical environment that was viewed as unchanging. In his response to Alfred Kroeber's criticism, Boas, who himself was looking to become a geographer in Germany in the 1880s, argued that the geographical determination of cultures is overrated (BoAs 1936:137), and instead of the geographical and ecological changes, it is cultural interactions and borrowings that should be studied.

The separation of nature and culture can not only lead to the anachronistic view of the natural environment, but also indirectly contribute to the timeless approach to culture and the human sphere. Adapting to the modernist epistemological horizon, modernist ethnographic/anthropological studies tended to view cultures that were separated from the changing European culture, "stuck" in a point in history, in a sort of anachronistic "ethnographic time", ignoring historicity (FABIAN 2002:25-35). Anthropological studies based on fieldwork often provided extensive depictions of the given cultures in the state in which the authors encountered them. The main reason for this was that in the case of societies without writing (and recorded history) (WoLF 1982), information about a given

\footnotetext{
${ }^{1}$ This paper was supported by Symbolic Landscapes and Ethnic Relations in Russia, a research program of the Hungarian State Research Fund, OTKA (project number K 81267).

${ }^{2}$ Instead of real place names and personal names, I use pseudonyms in the study.
} 
group was limited primarily to the period when the researcher was present. In retrospect, the functionalist school, which played a decisive role in the history of anthropology, is often criticized for having paid little attention to the historical changes in societies (WULF 2013:88-90).

Although the diachronic approach prevailed in both social and natural sciences, until the 1970s, only a small number of historical ethnographic works were published that examined the natural and social changes simultaneously and in conjunction with each other. Subsequently, however, the influence of environmental fixism (i.e., the theory that assumes the constancy of the physical environment) continuously declined within historiography and historical ethnography. The relationship between societies and the climate, as well as the natural environment, was initially considered to be unidirectional by historians presenting the long processes of history (LE RoY LADURIE 1972). According to this approach, climate change impacts environmental conditions, and thereby affects a given culture or society as well (the medieval European agricultural revolution or the Little Ice Age provide excellent examples of this).

Climate history studies have become an essential tool of historical analyses of changes in agricultural production, famines, and epidemics (WIGLEY - INGRAM - FARMER 1981; BEHRINGER 2010). The impact of human societies upon climate, by contrast, was regarded by historiography and ethnographic/anthropological research as insignificant and negligible until very recently; however, the challenges posed by global warming over the past two decades have garnered the attention of anthropologists, and today an increasing number of works addresses the problems caused by global climate change, as well as proposed local adaptation strategies. ${ }^{3}$

After recounting the geographical and climatic characteristics of Yakutia, my study presents the ever-changing husbandry that regulated the relationship between the Sakha communities and the subarctic landscape. The slow and collective changes in husbandry and climatic conditions have established a relative equilibrium in which no significant long-term fluctuations developed, placing the Sakha within and as part of the local ecotopes. This balance was first broken by the modernization efforts of the centrally planned Soviet economy, and global climate changes over the past two decades have also put a significant pressure on the relationship between the Sakha and their landscape. In my paper, I argue that the challenges caused by these rapid changes can be interpreted not only from ecological and economic perspectives, but also as a conflict that takes place in a community which is formed by the living environment and the Sakha together. This approach is what feeds the intimate view of the environment which can become a major resource for the successful response to contemporary challenges.

\section{YAKUTIA AND PERMAFROST SOIL}

Yakutia is characterized by the most extreme climatic conditions of the entire northern hemisphere. In the cold winter, the mercury often drops below $-60^{\circ} \mathrm{C}$, but summer temperatures reaching $+40^{\circ} \mathrm{C}$ is not uncommon either. The vegetation period is very

\footnotetext{
${ }^{3}$ For a summary of these works: HASTRUP - SKRYDSTRUP 2013.
} 
short; the snow begins to melt towards the end of April, while the first ground frost may be seen in late August. Thanks to this extremely cold climate, the vast majority of Yakutia's soil remains frozen in winter and summer, with only the top 1.5-2 meters of the surface soil thawing out in the summer. This eternally frozen ground is called permafrost soil. Such permafrost soils are found in the northern hemisphere mainly in Siberia, Alaska and the northern regions of Canada, while the entire region of Yakutia is essentially always frozen.

Global warming affects the arctic regions in particular. The extent of warming and the climatic and environmental changes caused by it are especially significant in the arctic and subarctic regions (GOLDSTEIN 2009:41-43). One of the most significant effects of the warming is the thawing, increased erosion and the humidification of permafrost soil (FEDOROv - Konstantinov 2009). This applies both to the meadows formed in thermokarst depressions (alaas), ${ }^{4}$ as well as the forests. In Yakutia, the lentil-shaped marshy thermokarst depressions formed during the Pleistocene, are immensely important for the cattle-based economy of the Sakha. In the Sakha language, these depressions are called alaas. At the confluence of the Aldan and Lena rivers (in Central Yakutia), these alaases (according to different estimates) cover $17-30 \%$ of the total surface area (KaTAMURA et al. 2006; TeLBISZ - NAGY 2008). The size of each alaas varies. Occasionally they may be larger than 65 square kilometers (like Toyon Mürü), with several villages located in them; at other times, however, they are unnamed forest clearings with a radius of just 100 meters. Alaases are meadow grasslands in a boreal forest (taiga) dominated by larches, with a lake or a swampy, soggy bed of a dried-up lake at the center (CRATE 2006:3). At the same time, this is a particular Yakutian ecotope, the creation and characteristics of which can at once be considered as natural and anthropogenic in origin. Although it is debated precisely which geographic processes were involved in the creation of alaases, it is commonly accepted that these big meadows can be found in the areas of pre-existing, expansive lakes created by the partial thawing of frozen ground (DESJATKIN 2008). Upon the thawing of the ground, first forest swamps (düöde) were created whose water surface continued to grow. These lakes then dried up, or the Sakha communities living there drained them (BosIKov 1991:112). Alaases are today the most important scenes of Yakut hay farming and grazing.

The horse- and cattle-farming Sakha settled and still live today in the largest numbers mainly in the alaas-dotted Central Yakutian plains. Following their northern migration approximately 800 years ago, ${ }^{5}$ the traditional horse and cattle breeding of the Sakha gradually adapted to the extreme climatic and geographic environment of Yakutia. Over the centuries, horses and cattle breeding took a shape specific for the area of Yakutia which is unique even in Siberia (ABramov - D'JAKonov 1990; VinokUrov 2001; GRANBERG - SOINI - KANTANEN 2009).

Due to the long and cold winters, cattle have to be kept in barns in Yakutia for nine months (from September to May), and for this period, two tons of feed (particularly hay)

\footnotetext{
${ }^{4}$ The lentil-shaped thermokarst depressions formed by the ice melting under the surface of the permafrost soil is called in Sakha alaas.

${ }^{5}$ Several theories and data exist about when the Sakha appeared in the Lena River basin. According to Anatoly Ignat'evich Gogolev's data, which is regarded as the benchmark, Sakha settlement in the area of today's Yakutia began with the appearance of the Kulun atakh culture, i.e., in the $13^{\text {th }}$ century (AlEKSEEV - RomANOva - SOKOLOVA 2012:61-63).
} 
per animal must be collected on average during the summer. Therefore, the meadows have an enormous importance in Sakha economy and environmental perception (CRATE 2007:161). Although more than half of the hay collected in Yakutia comes from the alaases (Bosikov 1991:25-27), there are other ecotopes that provide suitable space for Sakha hay farming. The Sakha use as hayfields the floodplains of rivers (khocho), the drier areas of marshlands located on higher ground (kyrdal), as well as the grassy plains (khonuu).

Global warming threatens this economic system based on meadow husbandry. In Central Yakutia, the annual average temperature rose $2-3^{\circ} \mathrm{C}$ since the $1970 \mathrm{~s}$, and the average temperature of the top layer of permafrost soil has increased nearly in the same proportion (ROMANOVSKY et al. 2007). In addition, rainfall has increased (IJIMA et al. 2012) and the snow-covered period has become shorter (IJIMA et al. 2007). This complex change resulted in the degradation of permafrost soil, which led to Yakutian meadows becoming increasingly unfavorable in terms of agricultural production. Some of the meadows became marshy, the soil's moisture levels rose, and in some places lakes formed on the meadows (CRATE 2008). These changes affect Sakha meadow farming acutely and urge the development of new ecological and agricultural adaptation strategies (CRATE 2011; 2013).

\section{THE BASIC FEATURES OF SAKHA MEADOW AND PASTURE HUSBANDRY}

Sakha large cattle breeding has gone through several changes after Russian colonization (i.e., after the 1630s). Consequently, one cannot talk about any traditional mode of production or meadow husbandry. We have detailed and in-depth ethnographic descriptions of this changing agricultural system following the activities of political exiles in Yakutia from the end of the $19^{\text {th }}$ century. An approximate picture of the production forms and operating units of the preceding period can be made solely on the basis of the economic and legal documents of the tsarist administration (MÉszÁros 2013:90-95). Ethnographic/anthropological works about the Sakha - adapted to the contemporary ethnographic information gathered by the exiled researchers - consider the period preceding the revolution and collectivization (turn of the $19-20^{\text {th }}$ centuries) to be the "traditional" economic system (AleKseev - Romanova - SoKolova 2012:141). Accordingly, the following is an account of the basic features of the horse and cattle breeding, as well as meadow husbandry practices in the period before collectivization.

Sakha economy was based on horse and cattle husbandry, with fishing, hunting and agriculture being only complementary. ${ }^{6}$ Among livestock animals, the horse was more important up until the beginning of the $19^{\text {th }}$ century, with cattle gaining more and more importance gradually (BASHARIN 1956:19-20; SEROSHEVSKIJ 1993:257). This change was accompanied by a proliferation of new forms of land use as well. While winter fodder for the horses, which roamed free, was only complementary, the Sakha kept their cattle in barns for nine months. Therefore, beginning in the $19^{\text {th }}$ century, the importance and

\footnotetext{
${ }^{6}$ In 1901, livestock farming made up almost two-thirds of the total agricultural production (ALEKSEEV - Romanova - Sokolova 2012:146).
} 
proportion of meadows has significantly increased in Yakutia, to the detriment of pastures. ${ }^{7}$ By the middle of the $20^{\text {th }}$ century, this process gradually yielded an even ratio of hayfields and pastures in agriculturally utilized areas (BASHARIN 1956:5; MATVEEV 1989:54).

The intensive use of hayfields demanded that the winter settlement (kystyk) be located in the higher part of the alaases in Central Yakutia, so that the hay harvested in the summer did not have to be transported over long distances in the winter. Summer settlements (sajylyk) were usually located 10-20 kilometers away from the winter settlements, in areas where the cattle found good pastures in the summer but could not damage the hayfields that were only partially blocked by fences. The average distance between winter and summer settlements is also indicated by the fact that ten kilometers is what the Sakha call one kös, that is, the distance of one migration. Because of the proximity of the two (winter and summer) settlements, the men often did not move to the summer settlements, but instead stayed at the alaas of the winter settlements in order to collect the hay from the nearby hayfields. Sakha households stayed at the summer settlements from late May to early September. In the autumn (late September, early October), until the first major and non-melting snow (kystyk khaar) fell, the men even stayed at a third, autumn settlements (otor) as well. The cattle grazed around these settlements as long as they could, then the men collected the remaining, lower-quality hay after the first frost.

Households that used the nearby winter settlements (living either on the same alaas or on adjacent alaases) established cooperative groups, usually conjoining 2-4 households. Furthermore, given the geographical conditions in the area, there were larger cooperative groups (tüölbe) as well, which aligned their economic activities (DARBASOV - EGOROV Solov'Ev 2000:45). The size of the cooperative groups was determined not primarily by the number of households, but rather by the number of livestock they tended to. Usually one tüölbe held 100-150 dairy cows, because that's the number of dairy cows one bull is able to serve. A herd of this size was held in Tobuluk by 12-18 households, corresponding with the average size of a kolkhoz, established around the middle of the 1930s. ${ }^{8}$

One household had an average of 5-6 dairy cows before collectivization (ALEKSEEv - Romanova - Sokolova 2012:146), but there were significant differences in the distribution of the stock. In Tobuluk, for instance, before collectivization, a third of the households only had one or two cows, as is clear from the distribution of the meadows. ${ }^{9}$

\begin{tabular}{|l|l|l|l|}
\hline & $0-5$ tons of hay & $5-10$ tons of hay & $10-20$ tons of hay \\
\hline Number of households & 44 & 81 & 20 \\
\hline Number of hayfield plots & 298 & 740 & 259 \\
\hline Average number of hayfield plots & 6.7 & 9.1 & 12.95 \\
\hline Total land area $($ ha) & 171.92 & 606.5 & 246 \\
\hline Average hayfield plot area $(\mathrm{ha})$ & 0.585 & 1.22 & 1.05 \\
\hline
\end{tabular}

Figure 1. The annual amount of harvest in I. Bajagantaj nasleg in $1917^{9}$

\footnotetext{
7 This process is closely related to the presence of the Russian state in Yakutia and its fiscal policies (MÉsZÁros 2013:73-83).

${ }^{8}$ The natural basis of collective production was initially considered even by the Soviet leadership to be the units of cooperative households within a geographical unit (urochishche) (DARBASOV - EGOROV - Solov'ev 2000:102).

${ }^{9}$ This table is based on GaByshev 1929:14.
} 
Sakha cows were not only small in size (350-400 kg) and extremely low maintenance, they also survived the long winter fodder period with a relatively small amount (i.e., less than one ton) of feed. Similarly to Sakha horses, cows also dug up the grass under the snow, so they were able to graze partially even in the winter. The milk from dairy cows did not exceed 800 kilograms a year, but it had a very high (5-7\%) fat content.

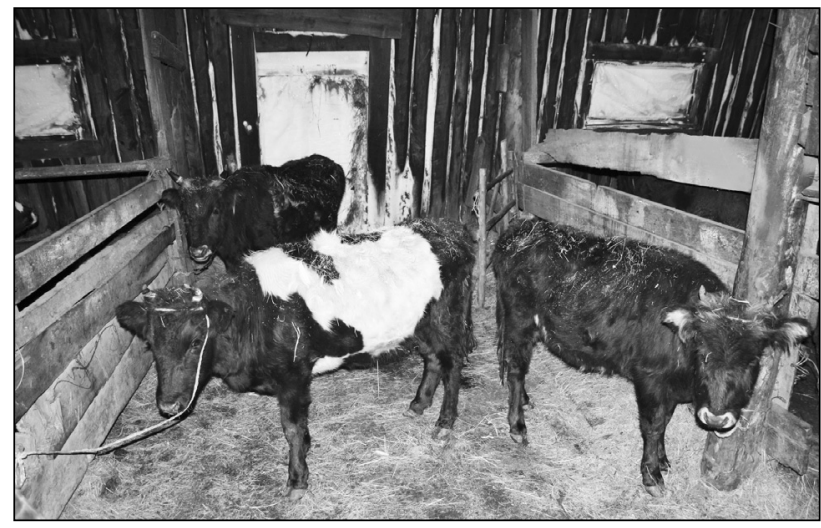

Figure 2. Sakha model cattle farm in Magharas, Yakutia, 2012. (Photo by Csaba Mészáros)

At the beginning of collectivization (in the 1930s), in order to increase milk production, the Soviet agricultural leadership replaced this low maintenance Sakha cattle variety first with the Russian Kholmogor breed, and starting in the 1960s, with the Austrian Simmental cows. Of the Sakha cattle fit for pre-collectivization farming practices, by 1990 only 900 remained in Yakutia, and today the vast majority of cattle in Yakutia are of the Simmental variety. The new European varieties require larger quantities (two or three times more) and better quality feed, therefore they are a lot more vulnerable visà-vis changes in the condition of the meadows. The Simmental cows' water needs are also greater than the Sakha cows', which creates further problems in their sustenance. Because of the change of breeds implemented in the $20^{\text {th }}$ century, pre-collectivization Sakha husbandry is thus irrecoverable today.

\section{THE JOINT EVOLUTION OF LANDSCAPE AND COMMUNITY}

In pre-collectivization husbandry, the grasslands and the Sakha people formed an indivisible system in which both parties were able to transform and change the other. First I point out the material features of this complex relationship, and later its spiritual characteristics.

Elsewhere I have already reported how the Sakha subsist in and inhabit the meadows, the alaases, and I also alluded to why they consider the alaases their home (MÉszÁRos 2012). However, the fact that the meadows provide a home for the Sakha did not prevent them from forming and transforming this ecotope in a variety of ways to adapt it to their farming objectives. For example, according to local memory in Tobuluk, before and after 
collectivization and all the way to the 1970s, there were three main methods of altering the landscape and the environment. Adapting to the features of the landscapes and ecotopes in the vicinity of the settlement, these methods allowed the locals to regulate the amount of hay harvestable from the meadows, fishing and water extraction opportunities, as well as the amount of gatherable firewood (Petrov - Petrov 2002:4-6).

1. The most common method was deforestation. Throughout Yakutia (especially in Central Yakutia), increasing the size of the alaas through deforestation was a common practice. Before the revolution and collectivization, the painstaking work of deforestation was undertaken because the people performing the clearing did not have to pay land tenure tax to the tsar for the meadows gained thus, and these areas were not included in the land fund of the local taxing units (nasleg) for a generation..$^{10}$ The meadows gained through deforestation were called cleared ground (soloohun sir). Locals (especially those who still go duck hunting in the spring and fall near the cleared lands) still remember which family's clearing was where.

The hay harvested from these cleared lands was of lower quality than those from the alaases, thus deforestation only spread in areas where there were no alaases, or only small ones. Accordingly, the areas northeast of Tobuluk were cleared by necessity, as continuous but moderate/poor quality hay meadows can be found only along the streams there. ${ }^{11}$

2. The other method was to drain the alaas (khoruu). Until the 1970s, only the alaases along larger waterways were drained. The areas gained by draining lakes and marshlands were similarly not included in the local land fund. The biggest problem with the drained areas was that they yielded low quality hay (ABRAMOv 2000:20-22), which is why these drained (but still soggy) areas were often used not as hayfields but as grazing pastures. The memories of the drainings are preserved not only in local memory - traces of the drain pipes from the 1950s are still visible south of Tobuluk.

A procedure connected to the draining was the removal of the tussocks (dulgha) as well. Harvesting hay with a scythe was much more difficult in boggy areas than on the flat meadows, and doing it with tractors was simply impossible. Whereas earlier the boggy areas were flattened by hand, in the era of sovkhozes the bogs were leveled by bulldozers.

3 . The third way to change the local ecotopes was to flood the alaas, creating artificial lakes (kupput küöl). In these cases, lakes were created primarily in places (mostly swampy, low-lying areas) where the water demand of those living in the area increased for some reason. In Yakutia, it is impossible to dig wells because of the ever-frozen ground.

\footnotetext{
${ }^{10}$ These areas are called "sejmelek sir". No land tax (ölbüge) was paid in tsarist Russia after these lands (whether they were cleared or drained). They were not part of the local redistribution fund.

${ }^{11}$ The Sakha distinguish two types of hay. One is the so-called alaas grass (alaas oto), which grows slowly in dry areas and has a high nutrient and vitamin content. The best hay in the alaas, according to locals, comes from the flowering meadow grasses (sibekki oto). At the same time, alaas grass does not grow reliably. In dry years, only a very small amount of hay can be harvested, and according to locals, it is mainly dry alaases that are harmed by locusts. The other type is the wetland grass (uu oto), which, unlike the alaas grasses, grows reliably and in large quantities every year, but is low in nutrient and vitamin content (ABRAMOv 2000:20-22). Hay quality has a significant impact on the fat content and taste of milk, which is why dairy cows are fed in Tobuluk with hay harvested from alaases (if possible).
} 


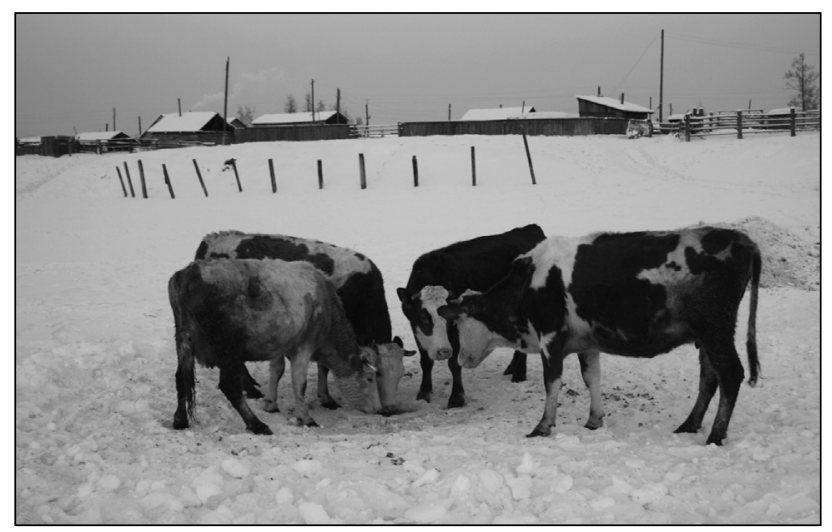

Figure 3. Simmentaler and Holstein Friesian cattle drink on the ice of an artificial lake in Tobuluk, Yakutia, 2011. (Photo by Csaba Mészáros)

The only way to obtain water is to collect the surface water. In October, the Sakha cut out the first crystallized ice from the lake's surface and store it outdoors in the winter, and in underground ice bunkers in the summer.

Locals do not worry about creating or filling lakes. The lakes were created primarily in sandy areas, as the water of a sandy lake (kumakh küöl) is cleaner and better tasting, according to locals, than that of a clayey, swampy soiled lake (n'amakh küol). The fish living in filled ponds (mainly crucian carp) also taste different from the ones in naturally formed lakes. Because of this, the artificial ponds near the villages are popular locations for late-autumn under-ice trawling. Locals will go fishing even on the lake called "Bie ölbüt", situated 50 kilometers from the village, despite the fact that there are other (large) lakes near the village. Nothing demonstrates the popularity of these artificial ponds better than the fact that Tobuluk Lake, in the immediate vicinity of the village, has been so overfished by the locals that the crucian carp went practically extinct. When in 1999 a Sakha healer came to the village, he immediately banned fishing in the lake, referring to the lake as having become ill. Since then, the lake has not been fished or hunted by locals, thus today it has become one of the most popular resting places for migratory waterfowl.

\section{LAND USE AND STATE MODERNIZATION}

The relationship between the Sakha and their landscape was significantly altered by Soviet economic and social modernization efforts, which derived from the modernist perspective that not only contrasted nature and human society, but also set them in a hierarchical relationship (RICHTER 1997:73). According to Soviet economic policies, the environment is primarily a virgin area to be subjugated, conquered, its assets waiting to be exploited for the best economic advantage (KULA 1998:60). The institutionalized mediation of Soviet-era economic directives was an integral part of the collectivization process, thereby changing the local communities' attitudes toward the environment. At the beginning of collectivization, that is, in 1929, in the Tobuluk area, the winter settlements were converted into kolkhoz 
centers (sugulaan) in accordance with the central economic directives (Kolesov 1931). It is in these kolkhoz centers that the first buildings appeared (kolkhoz administration, school, club, etc.), which became the imprints of the state's modernization efforts upon the alaases.

World War II played a major role in the next step of collectivization. From the Tobuluk area, which had more than 800 inhabitants, 145 men were conscripted into the Soviet Army during the war. In this village, too, producing for the front was associated with hunger and increased labor, and so in 1945, due to the shortage of people and animals, the former kolkhozes were no longer reorganizable. The centralization of the dwindling population and livestock was seen by Yakut leadership as an opportunity to increase labor productivity and more effectively control the population. The Sakha, who first settled along the alaases, then later along the sugulaans, now moved into the newly established villages throughout Yakutia. The former sugulaans of the smaller kolkhozes (which were also the tüölbe, groups of former winter settlements) now became the summer settlements of the large and unified kolkhoz brigades. Due to the lack of workforce, a portion of the alaases previously intensively used as hayfields came to be utilized as pastures, while some of the more remote sugulaan centers were completely abandoned by the Tobulukians. From this time on, the alaases were no longer the scenes of everyday life, and only those who worked in the sovkhoz brigades visited the alaases regularly.

In the 1970s, with the formation of the sovkhoz, production became even more large-scale: manual mowing was replaced by tractors, the locals worked in brigades, and hay was collected from the fields all at once, not in the context of cooperation as family, relatives and friends. Although centralization resulted in a more effective work by the brigades and enabled the harvesting of a much larger amount of hay (which the new Simmentaler varieties needed), it adversely affected the biodiversity of the alaas ecotopes (TROEvA et al. 2010:218). Increased herd sizes had a similarly adverse effect on the alaases. In addition, the larger herds appeared at the same time, and remained on a pasture longer, which also negatively impacted biodiversity (Troeva - Cherosov 2012). In years with extreme weather conditions (drought or too much humidity), meadows with limited species yield a hay harvest of significantly reduced quantity and quality. One of the most important negative impacts of global climate change and decreased biodiversity in the alaases in Yakutia is therefore uncertain crop yield.

The new cultivation systems and agronomic methods recommended by Soviet agricultural policy put a serious pressure on the permafrost soil. In accordance with the 1966 decision of the Communist Party of Yakutia, the agricultural use of the alaases intensified throughout Yakutia (VINOKUROV 2001:7-8). Accordingly, more and more areas were used for growing grains (primarily barley and rye). Many of the fields formerly used for hay were drained, plowed and irrigated. There was very little arable land in the state-owned farms of Tobuluk, yet in 1970 9\% of agricultural land in Yakutia was cultivated (MATVEEv 1989:54). Simultaneously, the volume of landscape modifications has significantly increased in the first decade of operation of these state farms. Within some state farms, the ratio of drained fields reached a settlement of the total of agriculturally utilized areas. Furthermore, between 1975 and 1985, the extent of arable land increased by approximately $50 \%$ (some of which were irrigated), and in order to make pastures more productive, some fields were flooded, and lakes were created in areas where water demand increased. The intensified land-use change put a considerable pressure on both the permafrost soil and the biodiversity of the vegetation. 
After the fall of the Soviet Union, that is, during decollectivization and the disintegration of socialist types of agricultural production, the number of cattle in Tobuluk decreased by about 30\% between 1992 and 1999, and the state-owned hayfields were allocated to local households. It was not only in Tobuluk that the decline of agricultural production was so dramatic. In Yakutia, there was a 40\% decline in livestock between 1990 and 2012 (VINOKUROV - PrOKHOROv 2013:6). The state farms no longer provided the locals' wages, and low market prices resulted in farming and livestock husbandry being unprofitable (DARBASOV - EGOROV - SOLOV'Ev 2000:75). As a result of these processes, not only the volume of livestock husbandry but also the extent of areas used and visited by livestock farmers was radically reduced in Tobuluk. The size of abandoned and uncultivated areas increased, and the perceived environment shrunk to a much smaller world, limited to the village square and some intensively used hunting areas. The reduction in the intensively used grazing areas was accompanied by overgrazing in pastures suitable for more economical use, which also decreased the biodiversity of the flora of these meadows.

The effects of state modernization led to a temporary increase in the volume of agricultural production in Yakutia (especially in the early 1980s), which in turn exerted an anthropogenic pressure upon the particularly vulnerable subarctic environment and the permafrost soil, leading to a severe economic downturn and environmental degradation due to the economic crisis caused by decollectivization as well as the concurrently happening climate change discerned by the locals. These negative trends not only altered the physical parameters of the environment, but also affected the spiritual characteristics of the meadows, lakes and rivers considered to be animate.

\section{ENVIRONMENTAL AWARENESS AND SPIRITUAL ECOLOGY}

To the Sakha, alaases are not just homes and meadows that formed Sakha husbandry and were themselves transformed through such husbanding, but animate entities with which the locals may come into contact in many ways. In Tobuluk, as in other Sakha villages, the alaases were protected and respected..$^{12}$ In addition to offering different views to the individuals looking at them, the alaases also possess different spiritual aspects and personality traits - thus, according to the Sakha, one has to act appropriately towards them. So every alaas is unique from a spiritual point of view.

To the Sakha, meadows and alaases possess a soul, a personality, and are therefore considered less as a landscape and more as a partner, a companion. The phenomenon of animism, which was seen in the $19^{\text {th }}$ century by scholars as a step in the development of religion (KUPER 1988:6-7), and in the $20^{\text {th }}$ century was surrounded for a long time by a lack of interest, was only discovered in the 1990s by anthropologists studying hunter-gatherer communities (BIRD - DAVID 1999). Among the Sakha, however, the perception of the world as animate does not extend to the whole environment; it is primarily the meadows and major open waters (rivers and lakes) that have personality traits. The alaases can also have spirits who mediate between the alaases and the people, but in most cases it is the alaas that is the animate entity, and the locals turn to it rather than to its host spirit.

${ }_{12}$ This does not mean that the alaas is necessarily interpreted as a ritual space, a holy place. For holy places, see NAGY 2007. 
The animate alaases, as any other living thing, are positioned in a certain direction. Thus, an alaas can be entered from the front and from the back, it has a head, and legs, too. The locals who are very familiar with the alaases can show one where the center of the alaas is and in which direction the "limbs" point. The circular fields are imagined as a kind of body. One does not step upon the body of the alaas without a reason. Traditionally, even the roads did not cross the alaases. Travelers not (or just slightly) associated with the area did not willingly enter the space of the alaas without a reason either.

Those who have specific capabilities are able to talk to the alaases. In Tobuluk, for example, Siider, who has healing powers (but is not practicing as a healer) has lived and worked on one alaas since 1999. According to the Tobulukians, Siider uses his special abilities for the propagation and care of livestock, making him the best dairy farmer in Yakutia whose cows produce three to four times more milk than the annual average. As a result of this, Siider has been awarded the Lenin Order of Merit and numerous other state accolades. The intimate relationship between him and the Tan'n'arang alaas is evident not only in the fact that it provides Siider with the strength for his work, the alaas also shelters and protects him.

In 1999, a female shaman (udaghan) once visited Tobuluk. Although Siider did not go into the village during the udaghan's visit, she sent word that she will come to him. During the evening herding, Siider noticed that a bird of prey perched on a tall larch at the edge of the alaas was watching him, but he knew that the bird was not going to fly into the alaas. Only upon nightfall did the udaghan enter (this time in the guise of a woman, not a bird of prey), but Siider was able to throw her off. According to Siider, he could only protect himself from the female shaman on his own alaas, and when healers arrive in Tobuluk, he prefers to stay on his own alaas, because "it is dangerous for two people with shamanic powers (d'oghurdaakh) to meet."

One of the most common forms of communication between people and alaases is the sacrifice. It is the fire lit in an alaas and the sacrificial food cast into that fire that creates the connection between man and alaas. The connection through fire is clear even in the Sakha language. While the name of the environment inhabited by man is sir-uot (i.e., fire and earth), the name of the non-human nature (ajylgha - i.e., "created") does not indicate the presence of man. The sacrificial food cast into the fire in the alaas is not intended for a specific god or spirit, but rather for the ancestors who lived there, or the alaas itself. The alaas is not divided into two parts during the sacrifice. It does not have a spiritual part, a spirit or god of the place that keeps watch over the "body," or the spatial embodiment of the alaas. This is a big difference compared to how the Sakha sacrifice in the forest. Sacrifices in forests and wooded areas are always offered to a host spirit (ichchi), and not to the limitless (and thus bodyless) forest of an unspecified expanse. The Sakha treat lakes similarly to the alaases.

The power of the alaas (and not of the host spirit of the alaas) is recognized by the Sakha throughout Yakutia (YAMADA 2004:224-225). In fact, one of the basic stereotypical traits (bütej kihi) ${ }^{13}$ of the Sakha of Central Yakutia are also determined by the alaases. Namely, the Sakha believe that the circular alaases enclosed by the forests breed robust, tough, stubborn but reliable people.

${ }^{13}$ In other words, "locked in, fenced in man". 
According to Sakha viewpoint alaases and lakes are actively involved as spiritual forces in those climatic and ecological changes that are caused by global warming in Yakutia. According to Ed'ii Dora, one of the most important Sakha female shamans ${ }^{14}$ the alaases and lakes are covered with veins, and communicate with each other through these blood vessels. These living organisms sense how people act towards them, and they tell each other (Protapopova 2002:60). As people's behaviors and activities no longer express respect for these landscapes, therefore the alaases and lakes punish the people with ecological and climatic anomalies (Protapopova 2002:63-64). According to Nikolaj Slepcov-Sylyk, another bioenergy healer, the "radiation" of the permafrost soil and its changes determine the health, traits and destiny of the Sakha living on it. Each alaas emits a different radiation, making the people who live there either happy and prosperous or unhappy and miserable (SLEPCOV-SYLYK 2013:34-38). Climatic changes have an overall negative impact on permafrost soil, so the eroding alaases found on permafrost ground also emit increasingly unfavorable radiation towards the Sakha living on them. The harmful responses of the animate alaases can only be mitigated by appropriate lifestyle choices and regular sacrifices (SLEPCOV-SYLYK 2013:24-25).

The examples of these two very popular and respected healers in Yakutia reveal the specific attitude with which Sakha spiritual ecology approaches the issues related to the phenomenon of global warming. The climate changes that are now causing major difficulties in Sakha economy are being interpreted by the locals not only as natural phenomena but also as a social problem. For many Sakha, lakes and alaases are not entities isolated from human culture, but parts of a larger community (society), which in Yakutia is formed by people, animals and landscapes. This approach establishes a personal relationship between man and landscape, which can become an important element of local adaptation strategies expedited by climate change.

\section{CHANGES AND DIFFICULTIES: THE VULNERABILITY OF THE LOCAL FARMING SYSTEM}

The intimate relationship that existed between the Sakha and the alaases was fundamentally changed not just by the rapid and radical reforms ushered in by the Soviet command economy, but also by the decollectivization and the economic depression that followed the fall of the Soviet Union. The impact of these factors are only further aggravated by climatic changes caused by global warming. While horse and cattle breeding among the Sakha has adapted to the challenges raised by the hopelessness of decollectivization and the fundamentally changed agricultural support system of federal Russia, ${ }^{15}$ it has yet to provide responses to the difficulties caused by climate change.

Local changes caused by global warming are felt by the Tobulukians, but their positive and negative impacts are judged differently. In 2013 the general opinion was that winters have not become noticeably warmer in the past few years. "In Yakutsk, they always cheat a little with the temperatures and do not represent the true values, to avoid

\footnotetext{
${ }^{14}$ I.e., "Sister Dora."

${ }^{15}$ The horse population decrease in Yakutia stopped in 2007, the cattle population decrease in 2011 (VINOKUROVA - PROHOROVA 2013).
} 
having to raise salaries. ${ }^{16}$ Here it is always 2-3 degrees colder than in Yakutsk, nothing has changed about that." However, my interview subjects regularly noted that every year there are significant differences in the overall severity of winter frost.

In Sakha folk wisdom, weather predictions are given an important place. A cold winter is normally associated with a thin snow cover, followed by a long and hot summer, according to the Sakha. A rainy autumn brings a thick snow blanket and a milder winter, and a rainy May and a cool, wet summer. So temperatures and precipitation are usually related in Sakha weather predictions. Locals detect changes in the amount and distribution of rainfall. "I can't recall this much rain since my childhood. I can't even go to my meadow, the grass can't even be cut. By the time I make it there, all will have rotted." Summer rains hinder work. While the spring rain is considered and called prosperous and a blessing by the Sakha (byjang), the word "rain" (ardakh) means bad weather, and figuratively it also means sadness.

The general belief is that the year is delayed: "I don't even recognize the weather, the frost, the snow, the heat are arriving later and later. Nature falls asleep and wakes up later and later." The first frost now comes not at the beginning of September or end of August, but only at the end of September; the winter snow starts falling later and lakes freeze later. The same is true for the summer season. The bright sunshine and intense heat also comes later, only at the end instead of the beginning of June.

However, the biggest problem is the unpredictability of weather. In the summer of 2012, the brigades went for hay in Kebeeji county, 400 kilometers west of Tobuluk, because they did not find enough fodder locally due to the huge summer drought. In 2005, 2006 and 2013, it was the large-scale summer rains that hampered work. Although the grass grew well in those years, harvesting was delayed and thus the hay quality was very low. Although in Yakutia the increase in summer rainfall and thus the oversaturation of alaas soil cause general difficulties, this problem has not yet affected the Tobuluk area. Whereas locals do report that the meadows northeast of the village are becoming more boggy and marshy, these meadows are now not being used anyway.

The vulnerability of the livestock economy in Tobuluk, which is particularly exposed to climate changes, has multiple reasons.

1. In the era of soviet time planned economy and collective production, the knowledge through which the locals were able to benefit from the alaases in various ways has faded. Prior to collectivization, alaases were not used only as pastures or hayfields, but also for hunting and gathering. The locals were much more aware of the peculiarities of the flora and fauna of the alaases. On the one hand, people lived on the alaases, in scattered settlements, so the alaas ecotopes provided an everyday experiences for them; they not only carried out their work on the alaases, but also lived there. The second reason for the departure from the alaases was that labor was becoming ever more technologized. While earlier the grass was mowed by hand, from the 1970s onwards this work was rarely carried out by hand. Mowing with a tractor is faster than manual mowing, but those doing the mowing are less able to detect a difference in the quality and type of the grass. Today a good reaper is required to have good technical skills rather than botanical knowledge.

\footnotetext{
${ }^{16}$ In Yakutia, state employees in certain professions that require working outdoors in extreme cold temperatures receive extra remuneration.
} 


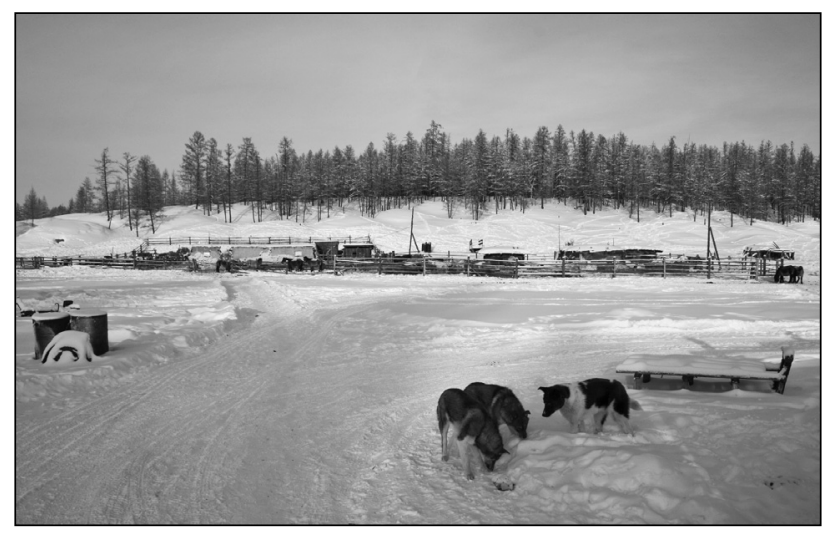

Figure 4. Winter settlement in an alaas, Yakutia 2012. (Photo by Csaba Mészáros)

In Tobuluk, young people can no longer distinguish between the different species, and they do not accrue much botanical knowledge outside of school biology classes.

The loss of local plant knowledge also means that the plants growing on the alaases or in the ponds are no longer collected. Plants widely consumed prior to collectivization, like the great burnet (ymyjakh, Sanguisorba officinalis), the grass rush (unnula, Butomus umbellatus), or the bulrush (kuba ahylyga, Typha latifolia) are now rarely found among the edible plants. Thanks to schooling, young people are now more familiar with the Russian name of many of these. The Yakut wormwood (üöre oto, Artemisia jacutica) that grows on drier alaases or close to old, abandoned settlements, as well as the tansy (timekh ot, Tanacetum vulgare), which prefers a more humid habitat, are still used today as medicinal herbs and seasonings (ToKumova - ToKumov 2011).

Knowledge on the flora of the alaases prior to the wide-range mechanization extended to also knowing which alaas was to be mowed when. The system of meadows that needed to be mowed sooner or later, as well as pastures that could be used for shorter or longer periods, determined the locations of the summer (sajylyk) and autumn (otor) settlements. However, after the 1970s in the era of state farms (sovkhozes), the order of mowing was regulated more by the ability to deliver the machinery to the meadows than by the condition of the grass grasslands. The lack of alaas-related botanical and ecological knowledge available to young farmers resulted in reapers becoming less and less able to respond on site to the challenges caused by climate change. Consequently, lower quality (acidic, low-nutrient) or less hay can be harvested each year.

2. Sovkhozes essentially produced for the state in the era of centrally planned collective production. Milkers and tractor operators of the sovkhozes received wages for their labor (they did not receive shares of crops or labor). Meat and milk produced by the sovkhozes were collected and processed by the state. When the sovkhozes disintegrated and state buy-ups gradually stopped, the livestock in Tobuluk decreased by nearly a third. However, switching to self-sufficiency was not possible, so the local cattle industry that has been gaining strength since 2011 is still primarily dependent upon state aid. That means, currently the local economy is not self-sustaining without state support. Although there are attempts in Yakutia to make the markedly disappearing Sakha cattle popular 


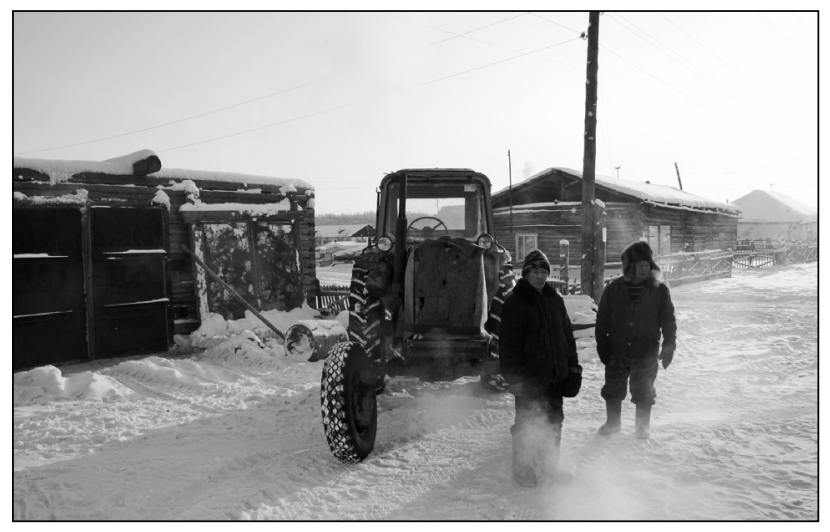

Figure 5. Farmers are heading to alaas in order to transport hay in the village Yakutia, 2011. (Photo by Csaba Mészáros)

again, and there are a few model farms in the republic, but there are no large-scale state programs supporting the breed change.

The transition to self-sufficiency was hampered by several factors, first of all the settlement structure. Following centralization, the Tobulukians left the alaases and moved into the villages. As a result, the utilization of pastures and hayfields reached very different levels. The common pastures near the village are overgrazed, the western and southern areas with a good network of roads are used extensively by locals, while the eastern and north-eastern areas less so (Mészáros 2013:142-144; 156-158). As some alaases and meadows are far from the village and no good roads lead there, today it seems nonsensical to use them, even if the pastures and meadows that are being used intensively produce insufficiently.

Further difficulties are posed by the composition of the cattle stock. Because of the state aid provided for each dairy cow, in Tobuluk today the proportion of cows in the herd is $40 \%$. Thus, the stock may become especially vulnerable if a sufficient amount of feed collected locally is not available to the locals. Unfavorable years (i.e., those in which they were not able to secure the right amount of fodder for the cattle) are called in Sakha et d'yl, or meat year. Namely, this is when the young animals that could not be out-wintered were slaughtered. The name of the year rich in fodder is üüt d'yl, or milk year. In these years, fewer cattle are slaughtered, and the bulk of the diet consists of dairy products. The consequence of the high proportion of dairy cows today is that farmers are forced to slaughter reproductive animals, which could lead to a significant volatility in the stock. So year after year, the villagers are compelled to import cattle feed produced in the central parts of Russia. Because of the village's dependence upon cattle feed, cattle breeding within the current economic framework cannot be considered self-sufficient and sustainable without external help.

Finally, another concern is that the village is now producing almost exclusively unprocessed raw materials (milk and meat). It is particularly striking that only a couple of families produce cottage cheese and butter locally. Villagers buy most dairy products in the local shops; some of these (such as condensed milk) come from Central Russia, while others come from Europe (such as the Swiss powdered milk used in tea). Although 
a variety of dairy products prepared in various ways were popular in Sakha diet, now almost no one prepares these in the village. The names of some dairy products mixed with fish, such as the barcha (dried crucian carp fermented in milk) and the agharan (the same made of other small fish) are now barely known. The milk produced in the village is delivered frozen to the county milk buyer, or the cream skimmed with a milk separator is sold to the same. The limited production of dairy products and their sale to a single buyer makes the village's cattle farming vulnerable and rigid.

3. Another reason for the vulnerability of the local husbandry is that young people are less concerned with the knowledge relating to the local spiritual ecology outlined earlier. The spirituality and interrelatedness that connects the older villagers to the alaases and forges them into a community is now becoming less intrinsic among young people who typically experience their environment through the opposition of the village and the "wild" nature surrounding the village (MÉszÁROS 2012: 24-25). Their encounters with the changes involving the alaases are lesser, and this also influences how the degradation of the alaases affects them. Research to date makes it clear that spiritualityladen and thereby protected areas are usually preserved in a better condition, and display more biodiversity (DUDLEY et al. 2005) as compared to those that are considered by a community to be wild, opposing the cultural sphere, and unmanageable.

\section{CONCLUSIONS}

Arctic and subarctic areas experience one of the most severe ecological and climatic changes caused by global warming. At the same time, climatic changes in the Arctic also have an enormous influence on the climate of the entire northern hemisphere. Therefore, exploring ecological changes observable on the local level in Siberia (and within that, in Yakutia) can significantly contribute to a clearer understanding of the global warming process and its impact. The Yakutian landscape cannot be viewed as a wild, unspoiled natural resource, because the Sakha and their husbanding, having lived there for centuries, left a definitive trace on the alaases, and the forests and lakes surrounding them (MORGENSTERN et al. 2013).

Husbanding has become particularly intense during the Soviet era. The centralization caused by collectivization, and the agronomic innovations introduced by state agricultural policy put considerable pressure upon the very fragile permafrost soil. Having had plowed, drained, irrigated and flooded the permafrost soil - which temporarily increased the volume of agricultural production during the time when state-owned farms were operated and generous government subsidies were distributed - has had the effect that today the challenges posed by soil degradation due to global warming are very difficult to meet. The problem lies not only in the humidification of previously cultivated soil which is now abandoned because of inefficient production, but also in the pastures and meadows that are still used being overgrazed and used too extensively. On the one hand, this reduces biodiversity, while on the other hand, it exposes the local economy to more and more unpredictable weather anomalies. Finally, it is important to mention the human factor. Working in and receiving wages from a centrally planned economic system, Sakha ecological and spiritual knowledge of the surrounding environment is incomplete. Observing the environment and experiencing its changes is now not even possible, 
because the areas used by village communities and available for everyday interactions have shrunk, and the number of people familiar with the more remote areas has also been reduced drastically. The intensive farming that resulted from collectivization, the economic depression associated with decollectivization, together with global warming, today represent a significant challenge for Sakha subarctic livestock husbandry, which must be responded to as soon as possible.

\section{REFERENCES CITED}

ABramov, Aleksej Fedorovich - D'jakonov, I. G.

1990 Sakha sirin küne-d'yla uonna sylgy iitiite [Yakutia's Weather and Horse Breeding]. Jakutskaj: Sakha sirineeghi kinige izdatel'stvota.

ABRAMOv, Aleksej Fedorovich

2000 Ekologo-biohimicheskie osnovy proizvodstva kormov $i$ racional'nogo ispol'zovanija pastbishch v Jakutii [The Ecological and Biochemical Basis of Producing Fodder and the Rational Use of Pastures in Yakutia]. Novosibirsk: Nauka.

Alekseev, A. N. - Romanova, E. N. - Sokolova, Z. P. (eds)

2012 Jakuty, Saha [The Yakuts]. Moskva: Nauka.

BASHARIN, G. M.

1956 Istorija agrarnyh otnoshenii v Jakutii [The History of Agriculture in Yakutia]. Moskva: Nauka.

BATESON, Gregory

2000 Steps to an Ecology of Mind. Chicago and London: The University of Chicago Press.

BEHRINGER, Wolfgang

2010 A Cultural History of Climate. Cambridge: Polity Press.

BIRD-DAVID, Nurit

1999 “Animism” Revisited:Personhood, Environment, and Relational Epistemology. Current Anthropology 40(1):67-91.

BoAs, Franz

1936 History and Science in Anthropology. A Reply. American Anthropologist, New Series 38(1):137-141.

Bosikov, N. P.

1991 Evolucija alasov central'noj Jakutii. [The Development of Alaas Landscape in Central-Yakutia]. Jakutsk: Institut Merzlotovedenii.

Crate, Susan A.

2006 Cows, Kin and Globalization. An Ethnography of Sustainability. Lanham: Altamira Press.

2007 "Eating Hay". The Ecology, Economy and Culture of Vilyui Sakha Smallholders of Northeastern Siberia. Human Ecology 36:161-174.

2008 Gone the Bull of Winter? Grappling with the Cultural Implications of and Anthropology's Role(s) in Global Climate Change. Current Anthropology 49(4):569-595.

2011 We are Going Underwater. Natural History 119(5):20-29. 
2013 Alamaj tyyn. Bülüü uluustarygar klimat ularyjyytyn tuhunan uonna baar kyhalghalar [Gentle Soul. About the Problems Caused by Climate Change Along the River Viliui]. D'okuuskaj: Bichik.

Darbasov, V. R. - Egorov, E. G. - Solov'ev, E. P.

2000 Osnovy razvitija kooperacii. Teorija, opyt, problemy [On the Development of Cooperative Farms. Theory, Experience, Problems]. Novosibirsk: Nauka.

DEGLER, Carl N.

1989 Culture versus Biology in the Thought of Franz Boas and Alfred L. Kroeber. New York - Oxford - Munich: Berg (German Historical Institute, Annual Lecture Series No. 2.).

Descola, Philippe.

2013 Beyond Nature and Culture. Chicago: University of Chicago Press.

DesJatkin, Roman V.

2008 Pochvoobrazovanie v termokarstovyh kotlovinah - alasah kriolitozony [Soil Formation in Thermokarst Depressions, in the Cryolite Zone of Alaas]. Novosibrisk: Nauka.

Dudley, Nigel - Higgins-Zogib, Liza - Mansourian, Stephanie

2005 Beyond Belief - Linking Faiths and Protected Areas for Biodiversity Conservation. Gland: WWF International.

FABIAN, Johannes

2002 Time and the Other. How Anthropology Makes its Object. New York: Columbia University Press.

Fedorov, Aleksander N. - Konstantinov, Petr Ya.

2009 Response of Permafrost Landscapes of Central Yakutia to Current Changes of Climate, and Anthropogenic Impacts. Geography and Natural Resources 30(2):146-150.

Gabyshev, M.

1929 O zemel'noi reforme v Iakutii. K VI vseiakutskomu s'ezdu sovetov. [On Land Reforms in Yakutia at the $6^{\text {th }}$ Meetings of Yakutia's Soviets.] Iakutsk: Izdanie narkomzema IaASSR.

Goldstein, Natalie

2009 Global Warming. New York: Infobase Publishing.

GranberG, Leo - SoIni, Katriina - Kantanen, Juha

2009 Sakha Ynagha. Cattle of the Yakuts. Helsinki: Academia Scientarium Fennica.

HASTRUP, Kirsten - SKRYDSTRUP, Martin (eds)

2013 The Social Life of Climate Change Models Anticipating Nature. London: Routledge.

ImIma, Yoshihiro - Fedorov, Alexander N. - Ohta, Takeshi - Kotani, Ayumi - Maximov, Trofim C.

2012 Recent Hydrological and Ecological Changes in Relation to Permafrost Degradation under Increased Precipitation in an Eastern Siberian Boreal Forest. In Hinkel, Kenneth M. (ed) Tenth International Conference on Permafrost. Volume 1. International Contributions, 161-166. Salekhard: The Northern Publisher. 
IIJIMA, Yoshihiro - Masuda, Kooiti - OHATa, Tetsuo

2007 Snow Disappearance in Eastern Siberia and its Relationship to Atmospheric Influences. International Journal of Climatology 27:169-177.

INGOLD, Tim

2000 The Perception of the Environment. Essays in Livelihood, Dwelling and Skill. London: Routledge.

Katamura, Fumitaka - FukUda, Masami - Bosikov, Nikolai P. - Desyatkin, Roman V. - Nakamura, Toshio - MoriIzumi, Jun

2006 Thermokarst Formation and Vegetation Dynamics Inferred from a Palynological Study in Central Yakutia, Eastern Siberia, Russia. Arctic, Antarctic, and Alpine Research 38(4):561-570.

Kolesov, G. G.

1931 Kolhozy Jakutii po perespisi $1930 \mathrm{~g}$. [Cooperative Farms According to the 1930 Census in Yakutia]. Jakutsk: Gosudarstvennaja planovaja komissija.

Kula, Erhun

1998 History of Environmental Economic Thought. London: Routledge.

KUPER, Adam

1988 The Invention of Primitive Society: Transformations of an Illusion. London: Routledge \& Kegan Paul.

Le Roy LADURIE, Emmanuel

1972 Times of Feast, Times of Famine. A History of Climate Since the Year 1000. London: Doubleday.

Matveev, I. A. (ed)

1989 Atlas Sel'skogo Hozjajstva Jakutskoj ASSR [Atlas of Agricultural Production in Yakutia]. Moskva: Glavnoe upravlenie geodezii i kartografii pri sovete ministrov SSSR.

Mészáros, Csaba

2012 The Alaas: the Interplay between Environment and Sakhas in Central-Yakutia. Halle: Max Planck Institute for Social Anthropology. (Max Planck Institute for Social Anthropology Working Papers 137.)

2013 Tekintély és bizalom. Kultúra és társadalom két szibériai faluközösségben [Prestige and Trust. Social Life and Culture in Two Siberian Village Communities]. Budapest - Pécs: MTA BTK Néprajztudományi Intézet - PTE BTK Néprajz - Kulturális Antropológia Tanszék - L’Harmattan.

MORgENSTERn, Anne - GÜNTHER, Frank - UlRICH, Mathias - Fedorova, Irina - RudAYA,

Natalia - BoIKE, Julia - SCHIRRMEISTER, Lutz

2013 Evolution of Thermokarst in East Siberian Ice-Rich Permafrost. A Case Study. Geomorphology 201(1):363-379.

NAGY, Zoltán

2007 Az öseink még hittek az ördögökben. Vallási változások a vaszjugani hantiknál [Our Ancestors Believed in Devils. Changes in the Religious Life among the Vasiugan Khantys]. Budapest-Pécs: MTA Néprajzi Kutatóintézet - PTE BTK Néprajz - Kulturális Antropológia Tanszék - L’Harmattan. 
Petrov, Anatolij Egorovich - Petrov, Egor Anatol'evich

2002 Khoduhany tupsaryy, tuhanyy [The Use and Upgrade of Pastures]. D'okuuskaj: Sakha Respublikatyn Üöreghin Ministerstvatyn Bastaky uonna orto anal üörekh departamenyn izdatelstvota.

Protopopova, Nina Innokent'evna

2002 Ed'ii Dora [Auntie Dora]. D'okuuskaj: Bichik.

RICHTER, Bernd Stevens

1997 Nature Mastered by Man: Ideology and Water in the Soviet Union. Environment and History 3(1):69-96.

Romanovsky, V.E. - Sazonova, T.S. - Balobaev, V.T. - Shender, N.I. - Sergueev, D.O.

2007 Past and Recent Changes in Air and Permafrost Temperatures in Eastern Siberia. Global and Planetary Change 56(3-4):399-413.

SEROSHEVSKIJ, Vaclav Leoplodovich

1993 Jakuty. Opyt etnograficheskogo issledovanija [The Sakhas. Findings of an Ethnographic Study]. Moskva: ROSPJEN

SLEPCOV-SYLYK, N. I.

2013 Dyhanie vechnoj merzloty [The Breathing of Permafrost Soil]. Jakutsk: Bichik. STEWARD, Julian

1955 Theory of Culture Change. The Methodology of Multilinear Evolution. Urbana: University of Illinois Press.

Telbisz, Tamás - NAGy, Balázs

2008 Termokarsztos mélyedések vizsgálata töbörmorfometriai módszerekkel, ürfelvételek alapján [Investigation of Permafrost Depressions based on Morphometrical Method and Satellite Images]. Karsztfejlödés 13:215-238.

Tokumova, Klara Petrovna - Tokumov, Petr Petrovich

2011 Törööbüt dojdubut emteekh üünejilere [Medicinal Herbs of Your Homeland]. D’okuuskaj: Bichik.

Troeva, Elena I. - IsAev, A.P. - Cherosov, M.M. - Karpov, N.S.

2010 The Far North. Plant Biodiversity and Ecology of Yakutia. Springer: London.

Troeva, Elena I. - Cherosov, Mikhail. M.

2012 Transformation of Steppe Communities of Yakutia Due to Climatic Change and Anthropogenic Impact. In Werger, J.A. - van StaAlduinen, Marja A. (eds) Eurasian Steppes. Ecological Problems and Livelihoods in a Changing World, 371-396. Springer. London.

VAKHTIN, Nikolaj

2001 Franz Boas and the Shaping of the Jesup Research in Siberia. In KRUPNIK, Igor - FitzHugh, William W. (eds) Gateways. Exploring the Legacy of the Jesup North Pacific Expedition, 1897-1902, 71-89. Washington D. C.: Arctic Studies Center and National Museum of Natural History and Smithsonian Institution.

VINOKUROV, I. N.

2001 Severnye tipy loshadej jakutskoj porody [The Yakut Breed of Northern Horses]. Jakutsk: RAN SO IPMNS. 
Vinokurova, D. E. - Prohorova, M. N.

2013 Sovremennoe sostojanie i razvitie zhivotnovodstva v Respublike Saha (Jakutija) [Current State and Development of Animal Husbandry in Yakutia]. Voprosy sovremennoj Ekonomiki, Ekonomika regionov, 1(4) http://economicjournal.net/2013/12/062/ (accessed February 20, 2015). УДК 636(571.56)

Viveiros de CASTRo, Eduardo

1998 Cosmological Deixis and Amerindian Perspectivism. The Journal of the Royal Anthropological Institute 4(3):469-488.

Wigley, Thomas M. L. - Ingram, Martin J. - FARMER, George (eds)

1981 Climate and History. Studies in Past Climates and their Impact on Man. Cambridge: Cambridge University Press.

Wolf, Eric

1982 Europe and the People Without History Berkeley: University of California Press.

WuLF, Christoph

2013 Anthropology: A Continental Perspective. Chicago: Chicago University Press.

YAMADA, Takako

2004 Symbiosis with Nature. a Message for the Reconstruction of Sakha Ethnicity and Identity. Senri Ethnological Studies 66:217-230.

Csaba Mészáros, PhD, is a research fellow at the Institute of Ethnology, Research Centre for the Humanities, Hungarian Academy of Sciences in Budapest. He has conducted subsequent fieldwork trips to the Republic of Sakha (Yakutia) since 2002. His major field of interest is Sakha environmental perception and local power relations in Siberian village communities. Email-address: csaba.meszaros@btk.mta.hu 